\title{
Development of Digital Literature-Laden Web in North Sumatra in Learning Courses Sanggar Bahasa dan Sastra Indonesia State University of Medan
}

\author{
Diah Eka Sari ${ }^{1}$, Emasta Evayanti $\mathrm{S}^{2}$, and Salmah Naelofaria ${ }^{3}$ \\ ${ }^{1,2,3}$ Faculty of languages and arts, Universitas Negeri Medan, Medan, Indonesia \\ E-mail: ekasarium@yahoo.com
}

\begin{abstract}
This research aims to develop and describe the results of the development of a web loaded with digital literature in North Sumatra in the course of learning courses sanggar Bahasa dan Sastra Indonesia. This research was conducted using the research and development (R\&D) method with the Four-D (4-D) model. The implementation stage consists of four steps, consisting of definition, design, development, and dissemination. The data collection instrument in this development research is questionnaires to obtain validity. Meanwhile, research instruments developed for web feasibility are charged with digital literature in North Sumatra in learning courses sanggar Bahasa dan Sastra Indonesia that have been compiled using validation sheets. Product prototypes are developed based on material, language, presentation, and display aspects. The results obtained after developing and programming a web containing digital literature North Sumatra in the course of learning courses sanggar Bahasa dan Sastra Indonesia, Faculty of Language and Arts, University of Medan obtained validation results, namely, for web usage with desktop reaches $100 \%$ eligibility rate and mobile usage reached $96 \%$. It can be concluded that the developed web is feasible to use.
\end{abstract}

Keywords: High Level Knowledge Ability Test, Temperature and Heat, Validity, Reliability

\section{INTRODUCTION}

The development of communication and information technology that grows fastly in this era has a huge influence on the learning process. Technology and Information have a very important role, especially in terms of providing innovative news to education. The use of technology and information is expected to form students and college students to be able to study independently. One of the uses of technology and information in learning innovation at the University of Medan is to create an innovation that is able to increase the success of the lecturing process in the classroom, for example developing something related to technology and information. During a pandemic like this, developing technology-based innovations will be very easy to realize. In practice, the learning carried out in the network requires several supporting devices in the form of laptops, gadgets, and several tools other communications that can access the internet and can be used anywhere and anytime. In this case, the main role of a lecturer is to be able to create innovations in support learning in the network that is being implemented. One of the things that can be developed in supporting the success of lecturing is by developing a web containing learning courses, in the study program
Indonesian language and literature education, through catching and fun learning media as a source of independent learning for students and college students. Web-based learning known as web-based training (WBT) or sometimes referred to as web-based education (WBE), is defined as an application of webbased technology in the education field to support the success of the learning process education. This webbased learning utilizes the internet network and the media site (website), which is reachable by electronic means such as gadgets, laptops, computers, or tablets. This learning is also known as e-learning. One of the subjects taught in Indonesian language and literature education is the learning courses sanggar Bahasa dan Sastra Indonesia. In general, the study material on the eye This course is about learning courses sanggar Bahasa dan Sastra Indonesia taught in schools. The learning courses sanggar Bahasa dan Sastra Indonesia consists of language teaching, both spoken and written literary writings and performances. Thus, the study material for this course is: language teaching both spoken and written and literary performances and teaching all three are in school (junior and high school) based on the revised 2013 curriculum edition. Process Lectures are presented in the form of theory and practice, with an emphasis on practice. In general, this 
course material contains an understanding of the Indonesian language and literature. The study materials or learning materials taught in the learning courses sanggar Bahasa dan Sastra Indonesia are news, article making, wall magazine, magazine making schools, clippings of rhymes, presenters (hosts), debates, speeches, poetry, rhymes, short stories, fairy tales, plays, language exhibitions, and literary performances. In line with the opinion of Sugirin, et al. (2011) show that it is very important to promote local cultural education intensively. It is meant as an effort to maintain the culture of the younger generation as well as a bulwark against the global culture that continues to erode. The participants (teachers) must understand the need for cultural insertion in teaching materials is like making cultural insertion efforts local/Indonesian in language learning. Although, it does not cover all components of culture so that students and college students can increase their cultural insight, especially the culture of North Sumatra. Through the material of the cultural context of North Sumatra in learning courses sanggar Bahasa dan Sastra Indonesia, students or college students. It is expected that it will be more catchy and easier to understand the aspects of the study or material that it will teach and be presented. In learning courses sanggar Bahasa dan Sastra Indonesia functioned not only as learning but also as effort preservation of local culture for the younger generation. Literature learning is expected to make a positive contribution in this era of globalization. The utilization of digital technology is focused on local perspectives towards a global perspective as a series to deal with the demands and expectations of technology and information development that is growing rapidly. Research conducted by Firmansyah, M. B. (2018) suggests that digital literature is an alternative to multidisciplinary learning with new presentations, especially in multimedia, multimodal, and interactive aesthetic packaging. Digital literature as well as innovative studies focusing on studies and techniques, visual dynamics, and materiality so that it can bring up a new definition of literary works. Thus, it can be concluded that learning digital literature is more directed towards learning multidisciplinary in multimedia, multimodal and interactive aesthetics, and not relates only to understanding definitions, elements and meanings through a literary approach. On this basis, the researcher conducted a study with the title "Development of digital literature-laden web in North Sumatra in learning courses sanggar bahasa dan sastra Indonesia state University of Medan" Based on the results of the identification of the problems above, the scope of this research problem is the need for web development containing North Sumatra digital literature in learning courses sanggar bahasa dan sastra Indonesia and prototype results in Web development containing North Sumatra digital literature in learning courses sanggar bahasa dan sastra Indonesia. The development of teaching materials aims to maximize the competence skills and knowledge of students and students of the
Faculty of Language and Arts, University of Medan. The product that the researcher will produce later is a web containing digital literature North Sumatra in learning courses sanggar bahasa dan sastra Indonesia, as well as supporting media in the form of learning videos and materials in the form of handbooks. This teaching material in the form of a video contains material about news, articles, wall magazines, making school magazines, clippings of rhymes, presenters (hosts), debates, speeches, poetry, rhymes, short stories, fairy tales, dramas, language exhibitions, and literary performances. This web development is expected to help students and students of the Indonesian Language and Literature Education Study Program in carrying out effective learning carrying elements of local wisdom of North Sumatra with a new model. Operationally The purpose of this study resulted in three things, namely: 1) Developing a web containing digital literature in North Sumatra in learning courses sanggar bahasa dan sastra Indonesia. 2) Describe a web assessment containing digital literature North Sumatra in the course of learning courses sanggar bahasa dan sastra Indonesia.

\section{METHOD}

This research uses Research and Development (R\&D) research methods. The steps for designing a web containing digital literature in North Sumatra can be detailed as follows: 1) Defining Stage (define). This stage aims to define the web containing North Sumatra digital literature in the curriculum. At this stage the steps are activities, namely curriculum analysis, concept analysis, and student analysis. 2) Stage The design aims to design a web containing Sumatran digital literature North. 3) The development stage, this stage aims at the production stage, namely: web development containing North Sumatra digital literature, and the post-production stage includes editing the attractive design of the web display. 4) Stage of dissemination, aims to distribute products to students of learning courses sanggar bahasa dan sastra Indonesia to determine the level of success of the product. This stage is intended to test whether the product is suitable for widespread circulation, or it is necessary to revise actions in several possible parts. This research was conducted at the Faculty of Languages and Arts, University of Medan, which is located on Jl. William Iskandar Ps. V, Kec. Percut Sei Tuan, District Deli Serdang, North Sumatra. The population in this study were all students and college students of the learning courses sanggar bahasa dan sastra Indonesia at University of Medan, totaling 137 people. The sample in the study only designates/represents which class will be the class experimental and control classes. In this case, the researcher appointed the Regular A class 2018 as the experimental class and Regular B 2018 as the control class. Where these two classes are considered a good class to study. The variable measured from this research is the success rate of web development containing North Sumatra digital literature in language and learning 
courses sanggar bahasa dan sastra Indonesia. The research variables are divided into two, namely independent variables, namely web development and the dependent variable is North Sumatra digital literature. The data collection technique in this development research is a questionnaire. A questionnaire was used to obtain valid data. Instrument research developed for data collection in research is an instrument Validation. Data collection in this study was carried out using the technique of questionnaire. The questionnaire used is a student needs questionnaire (students) and lecturers as well as questionnaires for validation of material and media expert lecturers. The questionnaire contains questions about what needs are really needed for students in Indonesian language and literature and how effectively these needs become levels the success of learning courses sanggar bahasa dan sastra Indonesia in the area of the University of Medan. The data analysis used in this research is descriptive statistics. Data obtained from the questionnaire were collected and grouped based on variables and types of respondents. The next step is to tabulate the data and perform calculations to conclude. The last step is to conclude the exposure data in the form of prominent findings and expert corrections so that they can meet research purposes. Validity data analysis, to analyze book validation used Likert scale based on validation sheet. The web user is said to be valid if it reaches validity above $75 \%$.

\section{RESULT AND DISCUSSION}

The draft results are about the initial description of web development containing digital literature North Sumatra in learning courses sanggar bahasa dan sastra Indonesia, Faculty of Languages and Arts, University of Medan are:

\subsection{Definition}

The initial stage of research is carried out and begins with the stage o analyzing the curriculum and analyzing the indicators of success based on the learning curriculum of the learning courses sanggar bahasa dan sastra Indonesia. In addition, carrying out a needs analysis of students for the development of teaching materials containing digital literature in North Sumatra with the help of the media web.

\subsection{Design}

After carrying out the analysis or definition stage, the next step is to design the web that contains digital literature North Sumatra on learning courses sanggar bahasa dan sastra Indonesia, that will be used as materials to teach learning courses sanggar bahasa dan sastra Indonesia. At this stage, the collection of teaching media from various sources is carried out the design or carry out the preparation of approximately any material that will be suitable if uploaded to the web that will be programmed.

\subsection{Development}

After the design stage has been applied, the next step is to implement the production stage, namely the web programming process that will be used. Researchers program the web by prioritizing convenience in accessing websites' digital literature to be used. The following is a programming process or web development:

Introduction

- Upload \& Set Up Database (in Figure 1)

- Deploying Process (in Figure 2)

- Server Log (in Figure 3)

Upload \& Setup Server, for hosting use to Heroku is used the php 7.0 programming language, shown in Figure 1.

Deploying Process for the Deployment process there are several stages, shown in Figure 2:

- Update Code

- Migration Database

- Plugin installation on server \& check in server health

After the website programming process is already applied, a page with address http://esastraunimed.herokuapp.com/ with the initial view of the web page can be seen in Figure 4. 


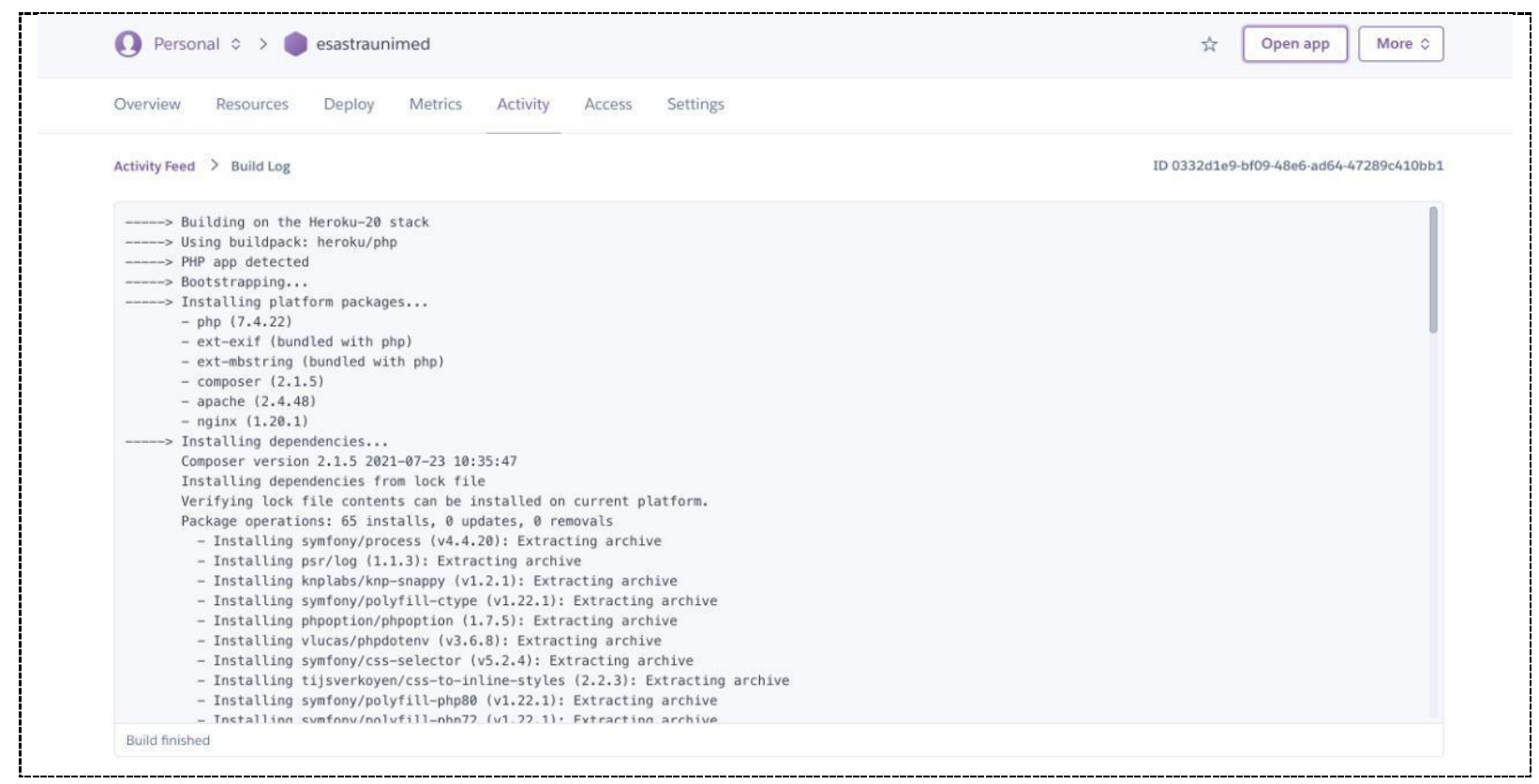

Figure 1. Upload and Setup Server

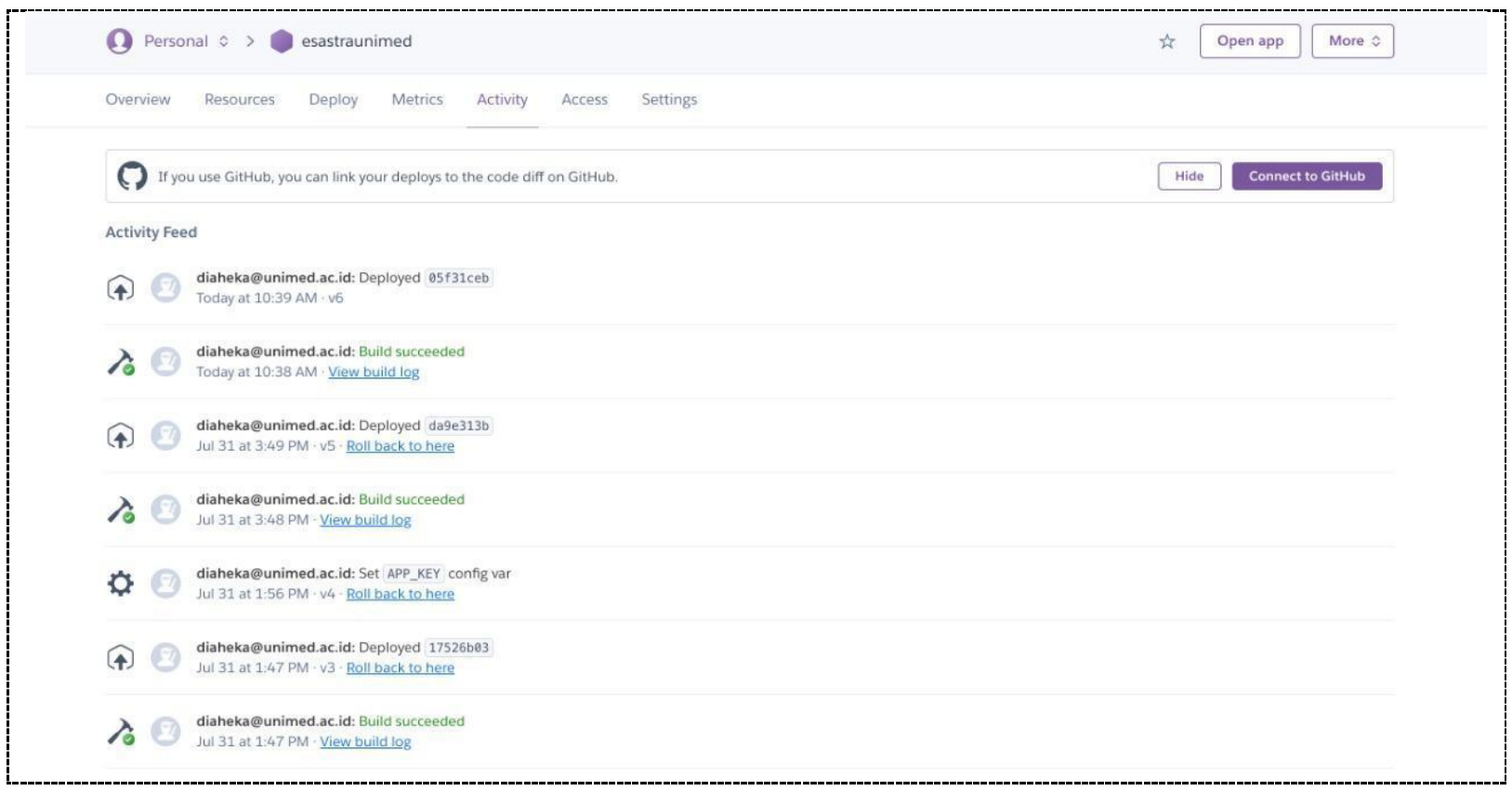

Figure 2. Deploying Process 


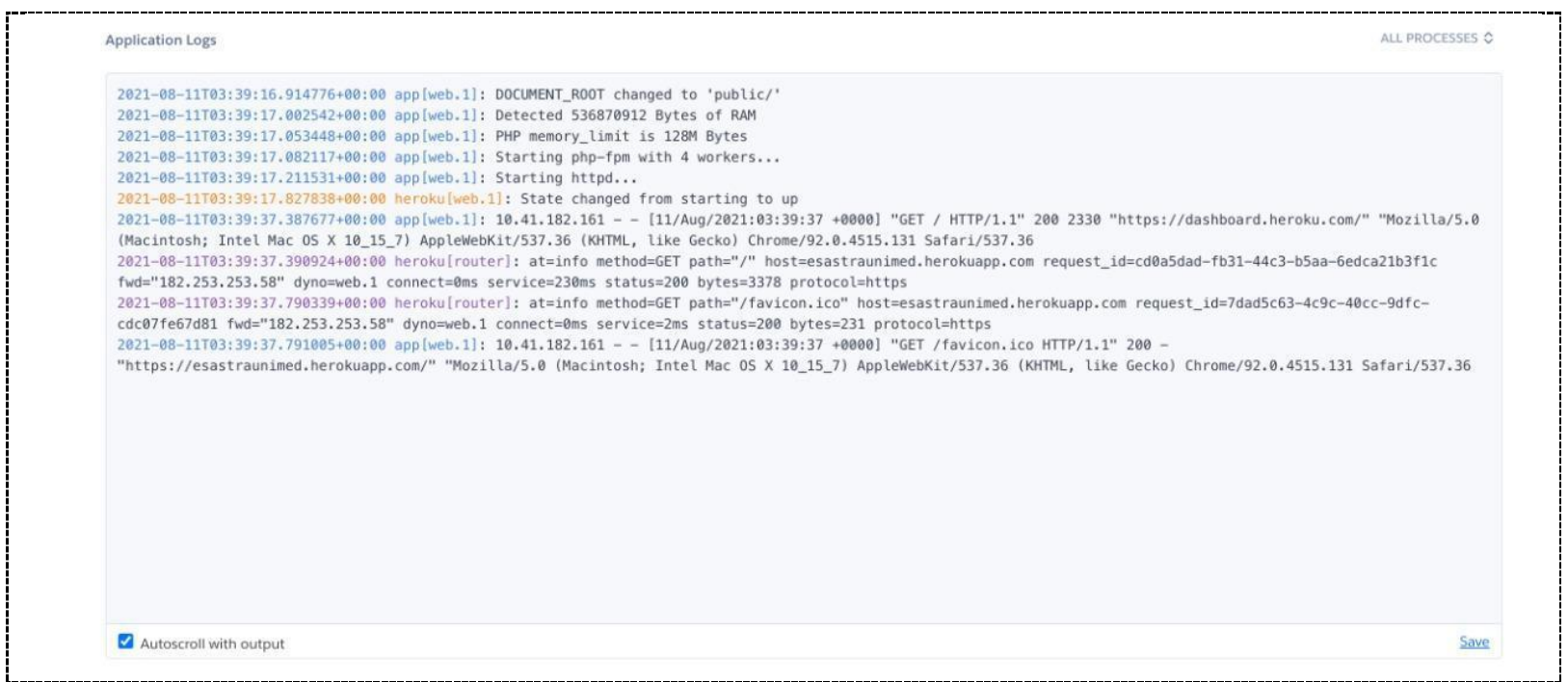

Figure 3. Server Log

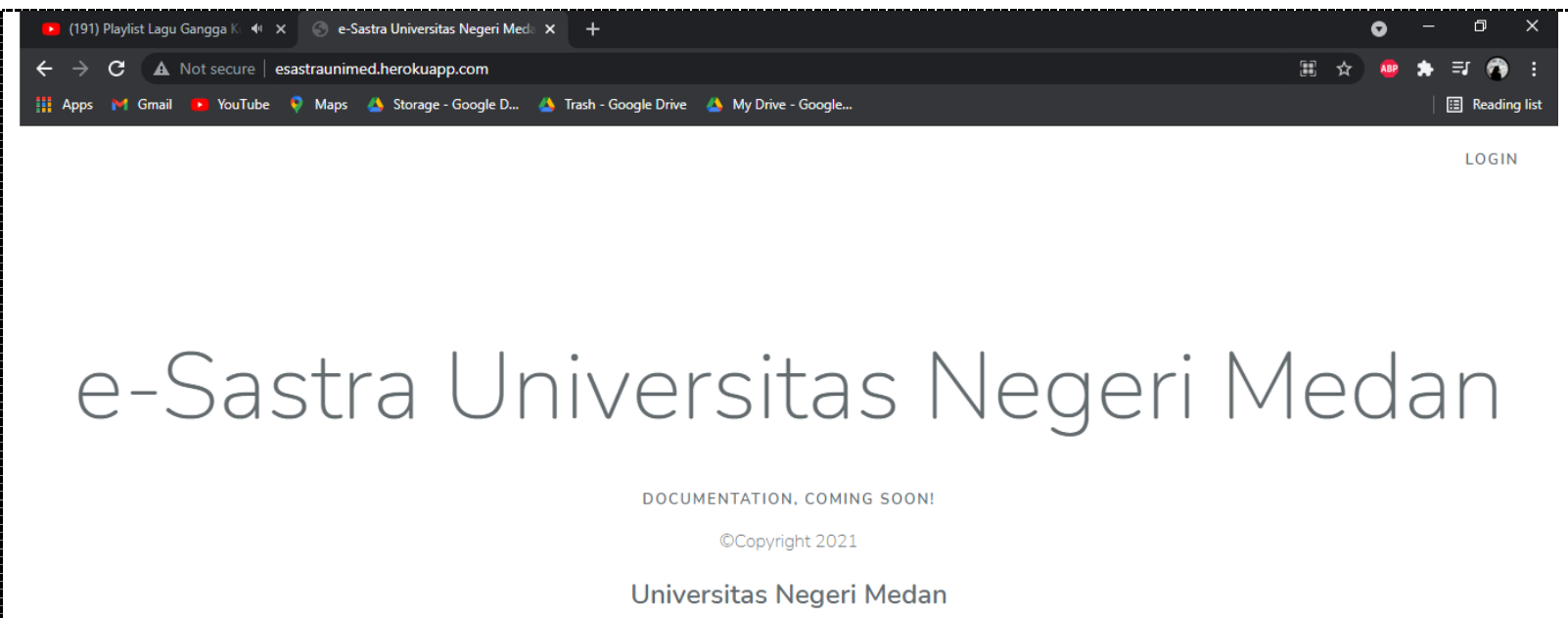

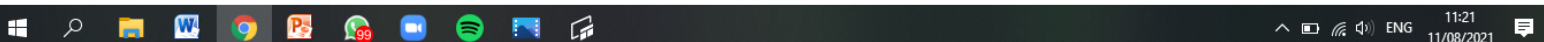

Figure 4. Homepage Website

Furthermore, the website validation stage is applied using page speed insights which are used to test the feasibility of a website page that has been developed. The results of the web validation test are as follows:

\subsubsection{Validation result using mobile}

In Figure 5 shows the validation results using mobile. From the validation results, the website developed achieved 95\% mobile usage results and from these results it was also concluded that the website is feasible for mobile use.

\subsubsection{Validation result using desktop}

In Figure 6 shows the validation results using desktop. From the validation results, the website developed reaches $100 \%$ desktop usage results, and from these results it is also concluded that the website is suitable for desktop use. 


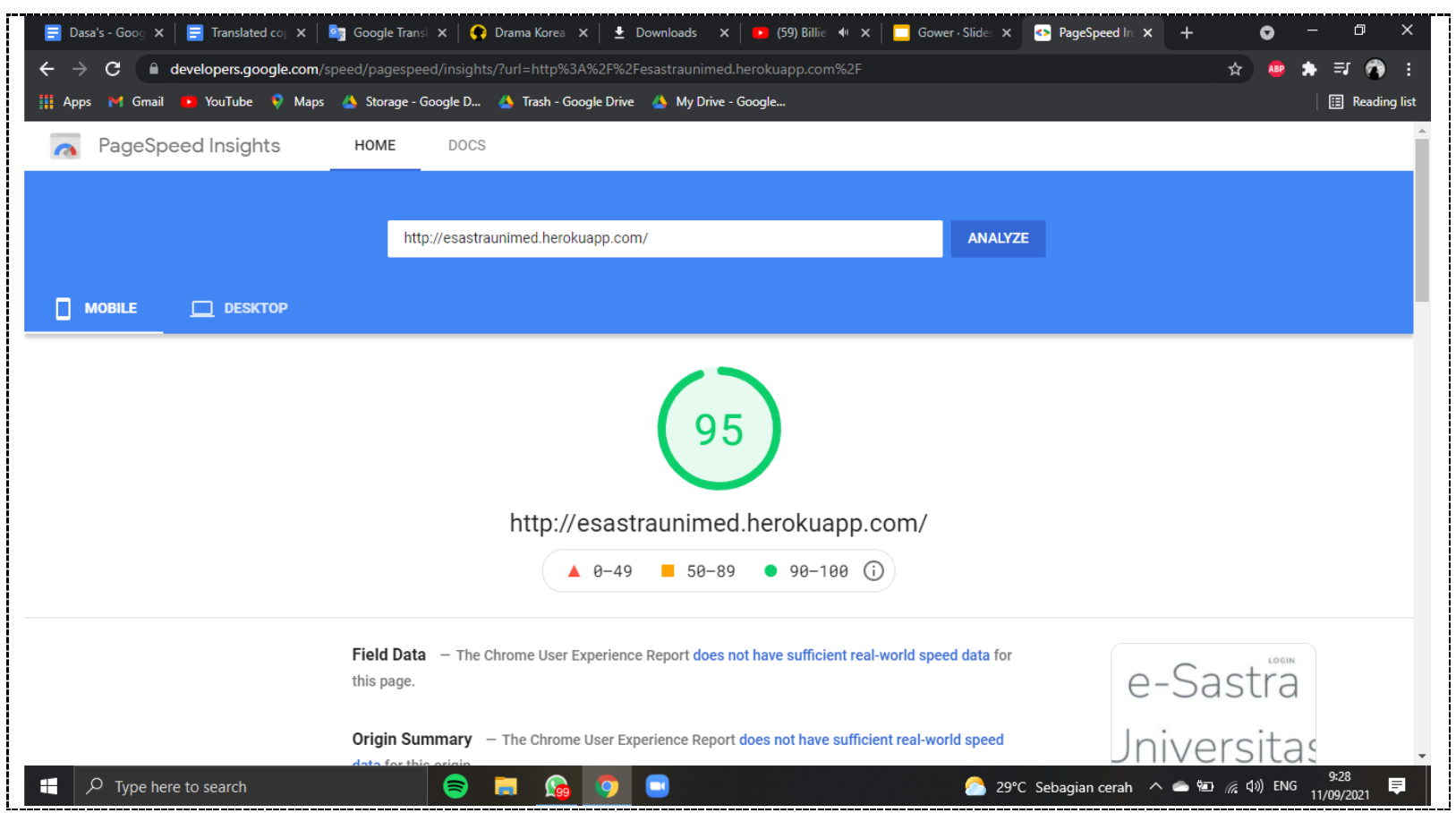

Figure 5. Validation result using mobile

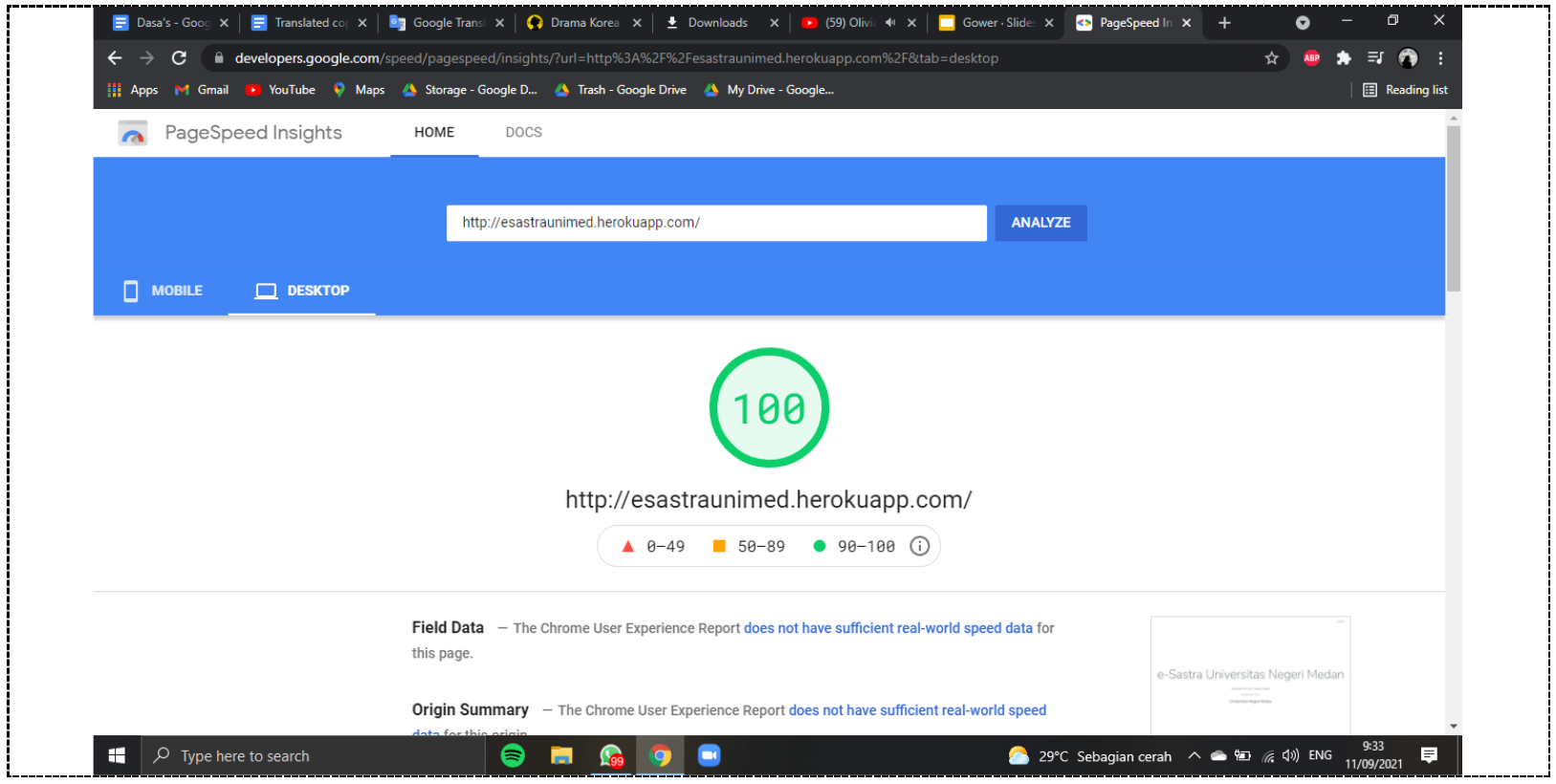

Figure 6. Validation result using desktop

\section{CONCLUSION}

The results obtained after developing and programming a web containing digital literature North Sumatra while learning Indonesian language and literature studios, Faculty of Language and Arts, University of Medan obtained validation results, namely, for web usage with desktop reaches $100 \%$ eligibility rate and mobile usage reached $96 \%$. It can be concluded that the developed web is feasible to use.

\section{REFERENCES}

[1] Depdiknas. 2008. Panduan Pengembangan Bahan Ajar. Jakarta : Depdiknas.

[2] Firmansyah, M. B. 2018. Konseptualisasi Pembelajaran Sastra Digital. Jurnal Ilmiah Edukasi \& Sosial, 9(1), 21-27.

[3] Godo, M.Agnes. 2008. "Cross-cultural Aspects of Academic writing:a Study of Hungarian and North American College Students L1 Argumentative Essays". International Journal of English Studies. 8/2:65-111. 
[4] Lukitaningrum, H. L. 2016. Pengembangan Media Pembelajaran Berbasis Web Pada Materi Basis Data Di Sekolah Menengah Kejuruan Kelas XI. Jurnal Elektronik Pendidikan Teknik Informatika, $5(5)$.

[5] Media. Depdiknas. 2006. Pedoman Memilih dan Menyusun Bahan Ajar. Jakarta: Depdiknas.
[6] Siswanto, Wahyudi. 2014. Sanggar Bahasa dan Sastra Indonesia. Tangsel: Universitas Terbuka.

[7] Sugirin, dkk. 2011. Pengembangan Buku Ajar Bahasa Inggris SMP Berbasis Multikultur sebagai Upaya Pemertahanan Budaya Lokal. Yogyakarta: PPS UNY. 